\title{
Research and Exploration of Teaching Method based on Creative Thinking in Data Structure
}

\author{
Xiaominng WANG \\ Department of Computer Science, inan University, Guangzhou, China \\ wxmsq@eyou.com
}

Keywords: data structure course; teaching method, creative thinking

\begin{abstract}
In this paper, we make some research and exploration on teaching method of data structure course based on creative thinking. We optimize the teaching system of data structure course, and focus on stimulating students' motivation and increasing their creativity by using different teaching ways, as well as lays emphasis on the integration of theory and practice. The practice shows that the teaching method based on creative thinking can give play to the initiative of students, and is be beneficial to train students' creative thinking and innovative ability, so that the teaching quality of data structure course is improved.
\end{abstract}

\section{Introduction}

Data structure is one of the most important courses for computer major, and is the basis for students to further study and develop high-level research. The main task of the course is to discuss the logical structure of various data structures, the storage structure and the algorithm of the operation ${ }^{[1]}$. The purpose enables students to learn to analyze the characteristics of the data structure, so as to select the appropriate logical structure, storage structure and the corresponding algorithm, and obtains the analysis way of the algorithm's time and space. The teaching of this course not only pays attention to students' the theory study, but also pays great attention to students' creative thinking and the practical ability training ${ }^{[2]}$. In order to achieve the purpose of the course, the optimization of teaching system and the innovation of teaching mode are important teaching steps, and the foundation of improving students' innovation ability and innovation consciousness.

Several works are available that were studied for teaching method of data structure course(e.g., [3]-[11] ). Chen et al. ${ }^{[3]}$ proposed a data structures excellent course construction and Wang et al ${ }^{[5]}$ analyzed teaching reform about data structure course. Chen et al. ${ }^{[6]}$ and Wang et al. ${ }^{[9]}$ explored teaching method of data structure experiment course. References ${ }^{[4,7,8,10,11]}$ proposed the teaching modes based upon cultivating applied talents. However, there are still many problems in data structure course, such as the defect of students' independent and cooperative learning, the insufficient of students' subjectivity playing, and so on.

In this paper, we make some research and exploration on teaching method of data structure course based on creative thinking. We optimize the teaching system of data structure course, and focus on stimulating students' motivation and increasing their creativity by using different teaching ways, as well as lays emphasis on the integration of theory and practice. The practice shows that the teaching method based on creative thinking can give play to the initiative of students, and is be beneficial to train students' creative thinking and innovative ability, so that the teaching quality of data structure course is improved.

\section{Teaching content update}

In this section, we present our works which optimize the teaching system of data structure as follows. 


\subsection{Introducing new developments in computer science}

We have modified data structure teaching program many times according to the concept of the thick foundation, wide caliber, strong practice and innovation. And we introduce the results of teaching reform and the latest development in computer science into data structure teaching, so that this course can not only maintains the stability of main body knowledge structure, but also keep the setting of the course content with the development of computer science. For example, we introduce the authentication data structure in cloud computing, and the search technologies in Google, Yahoo and Baidu. We explain these technologies, and make students to learn the latest developments and applications in time.

\subsection{Using data structure English textbook}

We use an Algorithms Introduction (English) as one of data structure teaching textbook. The purpose is to enable students to fully appreciate the idea of foreign teaching, and accept the latest knowledge and advanced technology, as well as learn the correct use of professional vocabulary and content. In addition, Jinan University is an overseas Chinese University, the students are both from the mainland students and overseas students, such as Hong Kong, Macao and Taiwan, and so on. Therefore, the English teaching material is more suitable for overseas students' study. After graduating, they return to the original place of residence and continue their studies, the English textbook has more special significance.

\section{Teaching methods and means}

In this section, we present our works in reforming the teaching methods and means of data structure course as follows.

\subsection{Teaching method reform}

(1) The teaching method is proposed, which combines the heuristic teaching with the multimedia lecture, to stimulate student interests in learning.

With the development of information technology, we continue to explore how to combine the heuristic teaching with the multimedia lecture. In the theoretical teaching of data structure, we use not only the combination the method of writing on the blackboard and the multimedia lecture, but also the virtual laboratory and network courses for teaching and learning, so that we fully carry out the teaching method of combining the heuristic teaching with the multimedia lecture. The teaching method of combining theory teaching with simulation experiment can inspire students' innovative thinking and fully mobilize students' initiative as well as creative thinking. The teaching method is very popular with the students, and we obtain a good teaching effect. At the same time, the method has been supported by many projects of the provincial and university education reform.

(2) The aided teaching mode of data structure is proposed based on students as the center and the teacher as the leading as well as the network course as the supporting platform.

The aided teaching mode can not only solve the problems of traditional teaching, such as the shorting of teaching resources, the lack of interaction between teachers and students, and the insufficient of students' subjectivity playing, and so on, but also encourage students to study independently and cooperatively, so that students' innovative ability and cooperative spirit are cultivated. Furthermore, the aided teaching mode can gradually expand the classroom teaching to the outside teaching, and enrich teaching contents and means.

(3) The experimental teaching mode is proposed based on cultivating students' innovation ability.

The experimental teaching should not only deepen the students' understanding for the theoretical knowledge of data structure, but also achieve the purpose of developing students' creative thinking and practical ability. To cultivate students' creative thinking and practical ability, we establish the experimental teaching system of multi-level and multi-module. We divide whole experiment contents 
into three levels such as foundation, design and the innovation. The structure is a shape of Pyramid, and highlights the idea of the modular teaching and multi-level progressive ideas. We start from the basic training, and then continually rise and deepen. Finally we realize the purpose of cultivating students' innovation ability and the ability to solve problems. We have applied the experimental teaching mode to the data structure course in Jinan University, and obtain very good results. For example, a number of innovation projects were approved by Guangdong province and Jinan University based on the innovation experiments of data structure.

(4) The effective segment of self-learning and counseling are formed by using network teaching platform and multimedia courseware.

We have developed the network teaching systems and multimedia courseware, such as the online quality demonstration course of the data structure, the virtual laboratory of the data structure, the online self testing system of the data structure, the homework management system the data structure and question answering system. Students can design and verify experiments by the virtual laboratory of data structure in anywhere and anytime, and they can carry out online testing by the online testing system of data structure in anywhere and anytime, so that students can assess their mastery of knowledge. Using the network answering system, the network homework management system, teacher can help students to solve the problems encountered in learning. These network teaching systems constitute the effective segment of self-learning and counseling, so that students can review, expand and evaluate their knowledge. Therefore, the network teaching systems are very beneficial to students' extracurricular learning.

\subsection{Teaching Means}

We combine the teaching systems that we develop with the course resources and teaching cases of the data structure to construct a teaching platform, which is an online virtual environment with the audio-visual. The teaching platform provides an interacting platform for teachers and students, and is an important supplement and expansion for classroom teaching and practice teaching. Moreover, we apply the teaching platform to the data structure teaching and improve the teaching quality.

\section{Examine and tutoring}

We reform the traditional examination method, and change the single written examination to the comprehensive examination which consists of the written examination, large homework and computer test. The comprehensive examination can avoid the phenomenon of the high scores and low abilities in a certain extent. Students think the comprehensive examination is good and flexible, and beneficial to the development of their comprehensive quality.

Moreover, we also enhance the after-school tutoring and answering questions, so as to find the problems of students' learning and help students to solve the problems in time.

\section{Conclusion}

Because of our continuous exploration on teaching method based on creative thinking, the teaching quality of data structure course is enhanced unceasingly, and students give a good evaluation for the data structure course. The data structure course was named the excellent course of Jinan University in 2004, and was named the excellent course of Guangdong Province in 2006, as well as was named the excellent resources sharing course of Guangdong Province in 2013.

\section{References}

[1] J. Qiu J., P. Wang, Z. Xu. Teaching Reform and Practice on the Course of Data Structure. Journal of Southwest China Normal University, 38(1) (2013) 139-142.

[2] L. L. Huo, Z. Wang, J. Su, Research on teaching method of data structure, Computer Education, 2 (2015) 73-76. 
[3] X.Y. Chen, K.C. Liu. Research and practice of the data structures excellent course construction. Journal of Nanyang Institute of Technology, 1(6) (2009) 121-12.

[4] Y.H. Zhang, The research of Data Structure Teaching based upon cultivating application-oriented personnel. Science \& Technology Vision, 4 (2015) 51-51.

[5] G.L.Wang, Z.G. Wei, H.T.Liang, L.K.Qiu, J.Zhang. The Brief Analysis of Teaching Reform about Data Structure Course. Search and exploration in laboratory, 26 (12) (2007) 284-285.

[6] H.M Chen, Q.Xiao, L.Z.Wang, B.Kou, Exploration of teaching method of data structure experiment course, Theory and Practice of Contemporary Education, 7(4) (2015) 66-68.

[7] X.Y.Lu, L.Wan. Teacher Blog and Teaching Innovation in "Data Structure", Higher Education Forum, 5(3) (2008) 37-39.

[8] L.P.Zhang, D.S. Liu, C.H,Wang. Computer applied personnel training and data structure curriculum reform. Computer Education, 5 (2010) 21-23.

[9] S.F.Wang, P.X. Cao, New mode of experiment teaching deepening theoretical teaching of data structure, Computer Education, 10 (2014) 97-98.

[10] M.Zhong. Teaching reform of data structure with the goal of cultivating applied talents, Computer Education, 14 (2014) 26-29.

[11] H.Xu, J.M.Zhou, Q.Gu, Strengthen Programming Thinking in Class and Agree with Practical Target in Teaching, Higher Education Forum, 1 (2013) 24-28. 